\title{
Glyphosate-Resistant Giant Ragweed (Ambrosia trifida L.) in Ontario: Dose Response and Control with Postemergence Herbicides
}

\author{
Joseph P. Vink ${ }^{1}$, Nader Soltani ${ }^{1 *}$, Darren E. Robinson ${ }^{1}$, François J. Tardif ${ }^{2}$, Mark B. Lawton ${ }^{3}$, \\ Peter H. Sikkema ${ }^{1}$ \\ ${ }^{1}$ University of Guelph, Ridgetown Campus, Ridgetown, Canada; ${ }^{2}$ University of Guelph, Guelph, Canada; ${ }^{3}$ Monsanto Canada, Guelph, \\ Canada. \\ Email: *nsoltani@ridgetownc.uoguelph.ca
}

Received March $6^{\text {th }}$, 2012; revised March 20 ${ }^{\text {th }}, 2012$; accepted April $13^{\text {th }}, 2012$

\begin{abstract}
Giant ragweed (Ambrosia trifida L.) is competitive with agronomic crops and can cause significant yield losses. Rapid adoption of glyphosate-resistant (GR) crops and a concomitant increase in the reliance on glyphosate for weed management has led to the evolution of GR giant ragweed in Ontario, Canada. Field studies were conducted to evaluate the level of resistance in giant ragweed biotypes from Ontario, and to evaluate the effectiveness of various postemergence (POST) herbicides in soybean (Glycine max L.). The effective dose (ED) to provide 50\%, 80\% and 95\% giant ragweed control was up to 1658,9991 and $>43200 \mathrm{~g}$.a.e. $\cdot \mathrm{ha}^{-1} 4$ weeks after application (WAA), respectively. For effective control, growers would need to apply glyphosate 18 times greater than the recommended field application dose. Glyphosate applied at the recommended field dose of $900 \mathrm{~g} \cdot$ a.e. $\cdot \mathrm{ha}^{-1}$ provided up to $57 \%$ control and resulted in soybean yield equivalent to the weedy check. Cloransulam-methyl applied POST provided up to $99 \%$ control, reduced giant ragweed density $98 \%$, reduced giant ragweed shoot dry weight $99 \%$ and resulted in soybean yield equivalent to the weed-free check. Chlorimuron-ethyl, fomesafen, imazethapyr and imazethapyr plus bentazon applied alone or with glyphosate did not provide adequate control of GR giant ragweed. Based on these results, some GR giant ragweed biotypes from Ontario have evolved a high level of resistance to glyphosate. Cloransulam-methyl applied POST was the only herbicide that provided adequate control and suggests that additional weed management tactics will need to be implemented in order to effectively manage GR giant ragweed.
\end{abstract}

Keywords: Bentazon; Chlorimuron-Ethyl; Cloransulam-Methyl; Fomesafen; Glyphosate-Resistant Crops; Herbicide-Resistant Weeds; Imazethapyr; Soybean

\section{Introduction}

Glyphosate [ $N$-(phosphonomethyl)glycine] was developed by John E. Franz of Monsanto Co., and was first tested as a herbicide in 1970 [1]. By 1974, glyphosate was commercially introduced in several markets as a postemergence (POST), non-selective herbicide for the control of weeds prior to crop planting [1-3]. Glyphosate inhibits the enzyme EPSPS (5-enolpyruvylshikimate 3-phosphate synthase) in the shikimic acid pathway and leads to the depletion of the aromatic amino acids tryptophan, tyrosine, and phenylalanine which are important for protein synthesis and secondary metabolism [4,5]. As a systemic herbicide, glyphosate is translocated from foliage to the roots, rhizomes, and apical tissues and controls hard-tokill perennials such as Canada thistle (Cirsium arvense

${ }^{*}$ Corresponding author.
L.), johnsongrass (Sorghum halepense L.), nutsedge (Cyperus esculentus L.) and quackgrass (Elymus repens (L.) Gould) [1].

Prior to the mid 1990's, the use of glyphosate was limited in field crop production because it also killed treated crops [6]. The introduction of glyphosate-resistant (GR) crops, mainly soybean (Glycine max L.), canola (Brassica campestris L.), cotton (Gossypium hirsutum L.) and corn (Zea mays L.) between 1996 and 1998 allowed growers to apply POST applications of glyphosate to the crop for the control of emerged weeds without crop damage [3,7]. Since then, GR crops have been rapidly adopted for reasons including excellent weed control, wide margin of crop safety, simplicity of application, lower cost of weed control, reduced fuel costs and improved soil conservation through no-tillage management [8,9]. In 2008, GR corn, cotton and soybean were grown 
on $77 \%$ of the total corn, cotton and soybean planted in the United States [7]. In eastern Canada, the area planted with GR corn and soybean reached $90 \%$ and $72 \%$, respectively in 2011 (StratusAgri-Marketing Inc., Guelph ON, personal communication).

GR crops have led to changes in herbicide use patterns because glyphosate is often the only herbicide used for weed control [7]. In GR cropping systems, glyphosate is often applied preplant (PP) or preemergence (PRE), POST in crop, and post harvest as a stand-alone selective herbicide [10]. From 1997 to 2003, the total active ingredient of glyphosate used in the United States in corn increased from 0.6 million $\cdot \mathrm{kg} \cdot \mathrm{year}^{-1}$ to 5.6 million $\cdot \mathrm{kg} \cdot \mathrm{year}^{-1}$. In soybean, glyphosate use has increased dramatically from 2.9 million $\cdot \mathrm{kg} \cdot \mathrm{year}^{-1}$ in 1995 to 41.7 million $\cdot \mathrm{kg} \cdot \mathrm{year}^{-1}$ in $2006[7,11]$.

The repeated use of glyphosate has increased selection pressure for weeds that are naturally difficult to control as well as the evolution of GR weed biotypes [12]. Glyphosate resistance was first reported in a rigid ryegrass population from an orchard in Australia, and soon after in goosegrass in Malaysia [13,14]. The first report of evolved glyphosate resistance in a GR cropping system was in Canada fleabane (Conyza canadensis L.) in the state of Delaware [15]. Glyphosate resistance has now been reported in 21 different weeds and is especially prevalent in the Amaranthus, Ambrosia, Conyza, and Lolium species [16].

Glyphosate resistance in giant ragweed (Ambrosia trifida L.) was first reported in Ohio, in 2004 [17], but has since been reported in nine additional states [16]. Westhoven et al. (2008) [18] suggested that GR giant ragweed could be found throughout the state of Indiana. GR giant ragweed biotypes from two populations in Arkansas have a 2.3- to 7.2-fold resistance level compared to a susceptible biotype [19]. In Tennessee, a GR giant ragweed biotype had a 5.3-fold greater level of resistance relative to a susceptible biotype [20]. In 2008, a giant ragweed biotype from a field near Windsor, Ontario, Canada was not controlled after two applications of glyphosate at the manufacturer's recommended dose. Seeds were collected and greenhouse experiments confirmed resistance to glyphosate. Plants from the Windsor population survived glyphosate up to two times the field dose (1800 g.a.e. $\left.\mathrm{ha}^{-1}\right)$ while the susceptible biotype was controlled at doses as low as a quarter of the field dose [21]. The giant ragweed biotype from Windsor was the first weed in Canada to evolve resistance to glyphosate and additional populations have since been confirmed at 47 additional locations [22]. Some biotypes are also resistant to the acetolactate synthase (ALS) inhibiting herbicide cloransulammethyl (unpublished data).

Giant ragweed is an erect, herbaceous, annual dicot weed that is a member of the Asteraceae family. Seedlings are easily identified by their large, spoon shaped cotyledons that are 9 to $16 \mathrm{~mm}$ wide, 25 to $45 \mathrm{~mm}$ long, and up to $2 \mathrm{~mm}$ thick [23]. Mature plants can grow up to six meters in height, and are often at least one meter taller than the crop with which it is competing [23]. Flowering occurs from mid-July to October, and a single plant can produce more than a billion pollen grains during its life cycle [23]. Pollen from ragweed is an important cause of hay fever; an allergenic reaction that affects an estimated 30 million people in the United States [24].

Poor control of giant ragweed in agronomic crops can result in large yield losses. In a study conducted by Webster et al. (1994) [25], giant ragweed outgrew soybean early in the season and maintained growth within the soybean canopy throughout the growing season. In the same study, giant ragweed interference from as little as one plant per $\mathrm{m}^{2}$ reduced soybean yield up to $77 \%$. In corn, yield losses as high as $90 \%$ were predicted if giant ragweed density was 14 plants per $10 \mathrm{~m}^{2}$ when it emerged simultaneously with the corn [26].

Unpredictable germination and emergence of giant ragweed has contributed to management challenges for growers. In previous reports, giant ragweed seedlings emerged in March before other annual weed species [27]. In an earlier report, giant ragweed finished emerging before May 15 [28]. More recent research suggests an early and prolonged emergence pattern. Schutte et al. (2008) [29] observed giant ragweed emergence in Ohio from April 5 to July 7. This early and prolonged emergence pattern has been observed in Ontario where giant ragweed will emerge as early as late March and continue through July (personal observation).

Glyphosate applied POST will no longer control GR giant ragweed biotypes in Ontario. Furthermore, prolonged emergence of giant ragweed complicates control strategies and results in late emerging plants that are not controlled with alternative PP or PRE herbicides. Giant ragweed can be controlled in corn with dicamba based herbicides, but options in soybean are limited [21]. The objective of this research was to determine the level of resistance to glyphosate in different GR giant ragweed populations, and evaluate the efficacy of various POST herbicides for the control of GR giant ragweed in soybean under field conditions in Ontario. This research will contribute towards the development of recommendations for the control of GR giant ragweed in Ontario.

\section{Materials and Methods}

A total of ten field experiments were established on Ontario farms with GR giant ragweed in 2011. One set of experiments evaluated the response of giant ragweed to 
varying doses of glyphosate (dose response), and another set evaluated various herbicides registered for POST application in soybean (POST herbicides). The experiments were conducted at locations near Windsor (L1 and L2), Belle River (L3), LaSalle (L4) and Amherstburg (L5). Glyphosate resistance was confirmed at each location prior to the establishment of field trials [22]. Field preparation included chisel plow, disking or no-tillage in the autumn followed by no-tillage management in the spring. Soil characteristics and agronomic information for each location are presented in Table $\mathbf{1}$.

The experiments were arranged in a randomized complete block design with three to four replications. Dose response treatments included glyphosate applied at 112.5, $225,450,900,1800,2700,5400,10,800,21,600$ or 43,200 g.a.e. $\mathrm{ha}^{-1}$. Herbicides included in the POST herbicides experiment were glyphosate $\left(900 \mathrm{~g} \cdot\right.$ a.e. $\left.\mathrm{ha}^{-1}\right)$ applied alone, and chlorimuron-ethyl (9 g.a.i. $\cdot \mathrm{ha}^{-1}+$ non-ionic surfactant at $0.2 \% \mathrm{vol} / \mathrm{vol}+28 \% \mathrm{UAN}$ at $2 \mathrm{~L} \cdot \mathrm{ha}^{-1}$ ), cloransulam-methyl (17.5 g.a.i. $\cdot \mathrm{ha}^{-1}+$ non-ionic surfactant at $0.25 \% \mathrm{vol} / \mathrm{vol}+28 \% \mathrm{UAN}$ at $2.5 \% \mathrm{vol} / \mathrm{vol}$ ), fomesafen (240 g.a.i. $\cdot \mathrm{ha}^{-1}+$ crop oil concentrate at $0.5 \% \mathrm{vol} / \mathrm{vol}$ ), imazethapyr (100 g.a.i. ha ${ }^{-1}+$ non-ionic surfactant at $0.25 \% \mathrm{vol} / \mathrm{vol}+28 \% \mathrm{UAN}$ at $2.0 \mathrm{~L} \cdot \mathrm{ha}^{-1}$ ), or imazethapyr plus bentazon (75 and $840 \mathrm{~g} \cdot$ a.i. ha $^{-1}+28 \%$ UAN at 2.0 $\mathrm{L} \cdot \mathrm{ha}^{-1}$ ) applied alone and in a tank mix with glyphosate $\left(900\right.$ g.a.e. $\left.h a^{-1}\right)$. The herbicide rates used in the POST experiment are the highest rate registered for use in Ontario. Each experiment included a weedy and weed-free check. All weed-free checks were maintained with glyphosate $\left(900\right.$ g. a.e. $\mathrm{ha}^{-1}$ ) plus 2, 4-D ester $\left(500\right.$ g.a.e. ha $\left.^{-1}\right)$ applied PP followed by hand hoeing as required.

Herbicides were applied with a $\mathrm{CO}_{2}$-pressurized backpack sprayer equipped with ULD 120-02 flat fan nozzles (Hypro, New Brighton, MN) calibrated to deliver 200 $\mathrm{L} \cdot \mathrm{ha}^{-1}$ of water at $210 \mathrm{kPa}$. Herbicide applications were made with a 1.5 meter boom with four nozzles spaced 50 $\mathrm{cm}$ apart over the center of the plot. Plots were six to eight $\mathrm{m}$ long depending on location. Size of giant ragweed and date of application varied according to location
(Table 1).

Visual estimate of soybean injury was evaluated up to 4 weeks after application (WAA) when soybean emergence corresponded with control assessment dates. Injury ratings were on a scale of 0 to $100 \%$, where a rating of 0 was defined as no plant injury and a rating of 100 was defined as plant death. Giant ragweed control was rated 1 , 2,4 and 8 WAA. Control was rated on a scale of $0 \%$ to $100 \%$, where 0 was defined as no control and 100 was defined as complete giant ragweed control. At 4 WAA, giant ragweed density and biomass (shoot dry weight) in each plot was determined by counting giant ragweed plants and cutting the plants at the soil surface from two $0.25 \mathrm{~m}^{2}$ quadrats. Plants were bagged by plot, dried at $60^{\circ} \mathrm{C}$ to a constant weight, and the dry weights were recorded. At crop maturity, soybean from two $m$ of row from each plot was harvested by hand. Soybeans were threshed in a stationary thresher, and the grain weight and moisture content were recorded. Yields were adjusted to $13.0 \%$ moisture.

\subsection{Statistical Analysis}

\subsubsection{Field Dose Response}

Data were subjected to ANOVA using the MIXED procedure in SAS (Ver. 9.1, SAS Institute Inc., Cary, NC). Variances were partitioned into the random effects of location, replication within location, and the location by dose interaction and the fixed effect of glyphosate dose. Significance of random effects and their interaction with fixed effects were tested using the Z-test of the variance estimate, while the significance of fixed effects were tested using the F-test. For giant ragweed control 1 and 2 WAA, there was a non-significant $(\mathrm{P}>0.05)$ location by dose interaction and data could be combined. For giant ragweed control 4 and 8 WAA, density, and shoot dry weight, locations were analyzed separately or combined in groups that resulted in a non-significant interaction. Giant ragweed shoot dry weight and density were expressed as percent of age the weedy check. Soybean yields

Table 1. Location characteristics, agronomic information, and giant ragweed height at the time of treatment application for field dose response and postemergence herbicides experiments conducted during 2011.

\begin{tabular}{|c|c|c|c|c|c|c|c|c|c|c|}
\hline Location & $\begin{array}{l}\text { Nearest } \\
\text { Town }\end{array}$ & $\begin{array}{c}\text { Soil } \\
\text { Texture }\end{array}$ & $\begin{array}{l}\text { Soil } \\
\text { OM }\end{array}$ & $\begin{array}{l}\text { Soil } \\
\text { pH }\end{array}$ & $\begin{array}{l}\text { Soybean } \\
\text { Cultivar }\end{array}$ & $\begin{array}{l}\text { Planting } \\
\text { Date }\end{array}$ & $\begin{array}{l}\text { Planting } \\
\text { Population }\end{array}$ & $\begin{array}{c}\text { Row } \\
\text { Spacing }\end{array}$ & $\begin{array}{c}\text { Treatment } \\
\text { Application Date }\end{array}$ & $\begin{array}{c}\text { Giant Ragweed } \\
\text { Height }\end{array}$ \\
\hline & & & (\%) & & & & $\left(\right.$ seeds $\cdot$ ha $^{-1}$ ) & $(\mathrm{cm})$ & & $(\mathrm{cm})$ \\
\hline 1 & Windsor & Sandy clay & 4.0 & 7.3 & Dekalb 31-10 & 7-June & 444,789 & 38 & 21-May & $2-12$ \\
\hline 2 & Windsor & Loam & 2.8 & 6.9 & Pioneer 92 Y80 & 15-June & 420,079 & 38 & 2-June & $4-14$ \\
\hline 3 & Belle River & Clay & 3.3 & 6.8 & Dekalb 31-10 & 7-June & 444,789 & 38 & 3-June & $2-25$ \\
\hline 4 & LaSalle & Loam & 2.6 & 7.5 & Dekalb 31-10 & 13-June & 467,029 & 38 & 21-May & $1-8$ \\
\hline 5 & Amherstburg & Clay loam & 3.7 & 7.9 & Pioneer 92Y80 & 8-June & 568,342 & 19 & 20-May & $1-9$ \\
\hline
\end{tabular}


were expressed as a percent of the weed-free check. At L3, the third replication was removed prior to analysis due to low giant ragweed density. At L5, plots 308 to 312 and 408 to 412 were excluded from the analysis after low giant ragweed densities were observed as a result of pooling water after rainfall. Soybean yield at L1 was excluded from the analysis due to giant ragweed shading of adjacent plots.

Non-linear regressions were performed using the PROC NLIN procedure in SAS. The regression models were chosen by examining scatter plots of the observed responses [30] or from previous reports in the literature [31]. A sigmoidal log-logistic curve:

$$
\mathrm{Y}=\mathrm{C}+(\mathrm{D}-\mathrm{C}) /\left\{1+\exp \left[\mathrm{B}\left(\ln (\text { dose })-\ln \left(\mathrm{I}_{50}\right)\right)\right]\right\}
$$

was used to regress giant ragweed control and soybean yield with glyphosate dose where $\mathrm{Y}$ is percent giant ragweed control or soybean yield, C is the lower limit, D is the upper limit, B is the slope of the line (negative for control), and $\mathrm{I}_{50}$ is the dose giving 50 percent of the response between the upper and lower limits. For soybean yield at L2, the log-logistic curve failed to fit the data and a segmented linear regression was used [30]. The equation(s) were of the form:

left segment:

$$
\mathrm{Y}_{\mathrm{L}}=\mathrm{a}_{0}+\mathrm{b}_{1} \times \text { dose }
$$

and right segment:

$$
\mathrm{Y}_{\mathrm{R}}=\mathrm{a}_{0}+\mathrm{b}_{1} \times \mathrm{j}+\mathrm{br}_{1}(\text { dose }-\mathrm{j})
$$

where $a_{0}$ is the intercept of the left segment, $b_{1}$ is the slope of the left segment, $\mathrm{br}_{1}$ is the slope of the right segment, and $\mathrm{j}$ is the junction point at which the two equations join. Giant ragweed density and shoot dry weight were regressed using an inverse exponential equation of the form:

$$
\mathrm{Y}=\mathrm{f}+\mathrm{g} \times \exp (-\mathrm{h} \times \text { dose })
$$

where $\mathrm{f}$ is the lower asymptote, $\mathrm{g}$ is the reduction in $\mathrm{Y}$ from intercept to $\mathrm{f}$, and $\mathrm{h}$ is the slope.

The effective dose (ED) of glyphosate was calculated using the appropriate regression equation. For giant ragweed control and soybean yield, $\mathrm{ED}_{50}, \mathrm{ED}_{80}$ and $\mathrm{ED}_{95}$ values represented the glyphosate dose that was required to provide $50 \%, 80 \%$ and $95 \%$ control or $50 \%, 80 \%$ and $95 \%$ soybean yield relative to the weed-free check, respectively. For density and shoot dry weight, $\mathrm{ED}_{50}, \mathrm{ED}_{20}$ and $\mathrm{ED}_{5}$ values were calculated to correspond with the dose of glyphosate required to reduce density and shoot dry weight by $50 \% 80 \%$ and $95 \%$, respectively.

\subsubsection{Postemergence Herbicides}

Data were subjected to ANOVA using the MIXED pro- cedure in SAS (Ver. 9.1, SAS Institute Inc., Cary, NC). Variances were partitioned into the random effects of location, replication (within location), and location by treatment interaction, and the fixed effect of herbicide treatment. Significance of random effects and their interaction with fixed effects was tested using the Z-test of the variance estimate, while the significance of fixed effects was tested using the F-test. For giant ragweed control and soybean yield there was a significant location by treatment interaction and locations were analyzed separately or combined into groups that resulted in a nonsignificant interaction. Giant ragweed density and shoot dry weight data could be combined. Residual plots were examined to confirm the assumptions of variance analysis (random, independent and homogeneous) and the Shapiro-Wilk test was used to confirm normality. When necessary, a transformation (natural log, square root, arcsine square root) of the data was applied and the transformation which generated the highest Shapiro-Wilk statistic was chosen. Giant ragweed density data were log transformed, shoot dry weight data were square-root transformed, and giant ragweed control data 4 WAA at (L1, L4 and L5), and 8 WAA at (L2 and L3) were arcsine square-root transformed. After interpretation, treatment means were transformed back to the original scale for presentation of the results. Means were separated using Fisher's protected LSD at $\mathrm{P}<0.05$.

\section{Results and Discussion}

\subsection{Dose Response}

The recommended glyphosate field dose of $900 \mathrm{~g} \cdot$ a.e. $\cdot \mathrm{ha}^{-1}$ did not provide acceptable control of GR giant ragweed. At 1 WAA, the dose required to provide $80 \%$ giant ragweed control was $6718 \mathrm{~g} \cdot$ a.e. $\mathrm{ha}^{-1}$ or eight times the recommended field dose. Glyphosate applied at $43,200 \mathrm{~g} \cdot$ a.e. $\cdot \mathrm{ha}^{-1}$ provided 93\% control and therefore the $\mathrm{ED}_{95}$ was predicted to be greater than the highest dose evaluated in this study (Table 2). At the earliest assessment, giant ragweed injury due to glyphosate treatment was rapid necrosis of the mature leaf tissue, as well as slight chlorosis of the newest leaves. This unique phenotypic response associated with the mechanism of resistance is consistent with a GR giant ragweed biotype from Indiana [32]. By 2 WAA, the $\mathrm{ED}_{50}, \mathrm{ED}_{80}$ and $\mathrm{ED}_{95}$ for GR giant ragweed was 1212,4332 and $37,764 \mathrm{~g} \cdot$ a.e. $\cdot \mathrm{ha}^{-1}$, or 1,5 and 42 times the normal field dose, respectively.

At the later control assessments (4 and 8 WAA), the GR giant ragweed population at L1 was more robust and resumed growth more rapidly than the giant ragweed at L2, L3, L4 and L5. Giant ragweed height in the weedy check was approximately $20 \mathrm{~cm}$ taller than the giant ragweed at the other trial locations. In previous research, the 
lethal dose (LD) required to kill $50 \%$ of susceptible giant ragweed accessions from Arkansas ranged from 164 to 335 g.a.e. $\mathrm{ha}^{-1}$ [19]. In contrast, $\mathrm{ED}_{50}, \mathrm{ED}_{80}$ and $\mathrm{ED}_{95}$ at L1 were 1658, 9991 and $>43200$ g.a.e. ha $^{-1}$, respectively. For the same level of control at the locations L2, L3, L4 and L5, glyphosate would need to be applied at doses of 1106, 3890 and $15957 \mathrm{~g} \cdot$ a.e. $\mathrm{ha}^{-1}$, respectively (Table 2). Based on the $\mathrm{GR}_{50}$ 's in this study, GR giant ragweed in Ontario is up to 10 -fold more resistant than a susceptible biotype from Arkansas. Furthermore, 95\% GR giant ragweed control may be achieved at doses 18 to $>48$ times the normal field dose. These doses are neither economical nor legal for growers in Ontario. By 8 WAA, the level of resistance at L1 further separated from the other locations. The $\mathrm{GR}_{50}$ was $18,982 \mathrm{~g} \cdot$ a.e. $\mathrm{ha}^{-1}$ compared to 2430 g.a.e. $\mathrm{ha}^{-1}$ at L2, L3, L4 and L5 combined: an 8fold difference in the level of control (Table 2).

Giant ragweed density and shoot dry weight generally correlated with the level of control. At L1, the doses required to reduce density by $50 \%, 80 \%$ and $95 \%$ were 6734,18179 and $>43200$ g.a.e. ha $^{-1}$, respectively. At (L2, L3, L4, L5) combined, the doses required to reduce den- sity by the same amounts were 6077, 13908 and 25757 g.a.e. ha ${ }^{-1}$, respectively (Table 2 ). The L1 biotype had a $1.0-, 1.3-$ and at least 1.7-fold greater resistance to glyphosate for reduction in density (Table 2). Reduction in giant ragweed shoot dry weight was similar to density, except for $\mathrm{ED}_{95}$ values. The doses required to reduce shoot dry weight by 50\%, 80\% and 95\% were 3813, 11143 and 22234 g.a.e. $\mathrm{ha}^{-1}$ for the L1 location and 953, 2665 and $>43200$ g.a.e. $h^{-1}$, respectively for the other locations combined. Based on the results from the combined locations, growers that would normally apply glyphosate at $900 \mathrm{~g} \cdot$ a.e. $\cdot \mathrm{ha}^{-1}$ would only achieve approximately $50 \%$ reduction in giant ragweed shoot dry weight (Table 2). Stachler (2008) [17] reported even higher levels of resistance in GR biotypes collected from Ohio and Indiana which required 8270 to $23940 \mathrm{~g} \cdot$ a.e. $\mathrm{ha}^{-1}$ glyphosate to reduce shoot fresh weight by $50 \%$.

Higher doses of glyphosate were required to achieve soybean yields comparable to the weed-free check. For locations combined (L3, L4, L5), the doses required to achieve $80 \%$ and $95 \%$ of the weed-free check were 6931 and $13785 \mathrm{~g} \cdot$ a.e. $\mathrm{ha}^{-1}$, respectively. These doses are 7.7-

Table 2. Dose response, segmented linear, and inverse exponential parameters for giant ragweed control 1, 2, 4 and 8 WAA, density, and shoot dry weight and soybean yield for field dose response experiments conducted in $2011^{\mathrm{a}}$.

\begin{tabular}{|c|c|c|c|c|c|c|c|c|}
\hline \multirow[b]{2}{*}{ Dose response } & \multirow[b]{2}{*}{ Location(s) } & \multicolumn{4}{|c|}{ Regression parameters $^{\mathrm{b}}( \pm \mathrm{SE})$} & \multicolumn{3}{|c|}{ Glyphosate dose $\left(\mathrm{g} \cdot \text { a.e. } \cdot \mathbf{h a}^{-1}\right)^{\mathrm{c}}$} \\
\hline & & $\mathrm{D}$ & $\mathrm{C}$ & B & $\mathrm{I}_{50}$ & $\mathrm{ED}_{50}$ & $\mathrm{ED}_{80}$ & $\mathrm{ED}_{95}$ \\
\hline \multicolumn{9}{|l|}{ Giant ragweed control } \\
\hline $1 \mathrm{WAA}$ & $1,2,3,4,5$ & $93.4(1.5)$ & $0.0(0.0)$ & $1.1(0.1)$ & 1327(70.6) & 1508 & 6718 & $>43200$ \\
\hline $2 \mathrm{WAA}$ & $1,2,3,4,5$ & $96.5(1.4)$ & $0.0(0.0)$ & $1.2(0.1)$ & 1140 (56.6) & 1212 & 4332 & 37764 \\
\hline \multirow[t]{2}{*}{4 WAA } & 1 & $94.1(5.2)$ & $0.0(0.0)$ & $0.9(0.1)$ & $1443(277.2)$ & 1658 & 9991 & $>43200$ \\
\hline & $2,3,4,5$ & $100.0(0.0)$ & $0.3(2.2)$ & $1.1(0.1)$ & 1113 (83.6) & 1106 & 3890 & 15957 \\
\hline \multirow[t]{2}{*}{8 WAA } & 1 & $100.0(0.0)$ & $4.0(3.4)$ & $1.6(0.4)$ & $19974(3042.7)$ & 18982 & $>43200$ & $>43200$ \\
\hline & $2,3,4,5$ & $100.0(0.0)$ & $2.1(2.9)$ & $1.0(0.1)$ & $2536(288.1)$ & 2430 & 10086 & $>43200$ \\
\hline Soybean yield & $3,4,5$ & $100.0(0.0)$ & $25.9(4.6)$ & $2.4(0.9)$ & $4557(837.1)$ & 3349 & 6931 & 13785 \\
\hline Segmented linear & & $\mathrm{a}_{0}$ & $b_{1}$ & $\mathrm{br}_{1}$ & $\mathrm{j}$ & & & \\
\hline Soybean yield & 2 & $10.2(8.1)$ & $2.1(2.4)$ & $7.8(1.6)$ & $4.8(1.8)$ & 5762 & $>43200$ & $>43200$ \\
\hline Inverse exponential & & g & $\mathrm{f}$ & $\mathrm{h}$ & & & & \\
\hline \multirow[t]{2}{*}{ Giant ragweed density } & 1 & $86.3(39.1)$ & $6.0(38.7)$ & $1.3 \times 10^{-4}$ & - & 6734 & 18179 & $>43200$ \\
\hline & $2,3,4,5$ & $101.8(11.6)$ & $0.0(0.0)$ & $1.2 \times 10^{-4}$ & - & 6077 & 13908 & 25757 \\
\hline \multirow[t]{2}{*}{ Giant ragweed shoot dry weight } & 1 & $80.5(9.9)$ & $0.0(0.0)$ & $1.3 \times 10^{-4}$ & - & 3813 & 11143 & 22234 \\
\hline & $2,3,4,5$ & $83.3(6.4)$ & $6.2(4.3)$ & $6.7 \times 10^{-4}$ & - & 953 & 2665 & $>43200$ \\
\hline
\end{tabular}

${ }^{\mathrm{a}}$ Abbreviations: WAA, week after application; ${ }^{\mathrm{b}}$ Regression parameters: Dose response, D, upper limit; C, lower limit; B, slope of the line at $\mathrm{I}_{50}$; $\mathrm{I}_{50}$, rate required for $50 \%$ response between upper and lower limit. Segmented linear, $a_{0}$, intercept of left segment; $b_{1}$, slope of the left segment; br ${ }_{1}$, slope of the right segment; $j$,

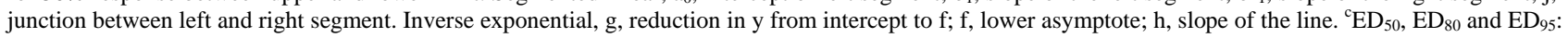
Rate required to achieve $50 \%, 80 \%$ and $95 \%$ giant ragweed control and soybean yield compared to the weed-free check, and $50 \%$, $80 \%$ and $95 \%$ reduction in giant ragweed density and shoot dry weight compared to the weedy check, respectively. 
to 15.3-fold greater than the recommended dose. At L2, poor soybean emergence due to heavy rain after planting resulted in the formation of a "crust" at the soil surface. As a result, soybean yield did not respond similarly to the other locations. The doses required to achieve soybean yield equivalent to $80 \%$ and $95 \%$ of the weed-free check were greater than the highest dose evaluated in this study (Table 2).

GR giant ragweed populations vary in the level of resistance. Based on the results of this research the $\mathrm{ED}_{50}$ and $\mathrm{ED}_{95}$ for $\mathrm{GR}$ giant ragweed at 4 WAA ranged from 1106 to 1658 and 15957 to $>43200$ g.a.e. ha $^{-1}$, respectively. This corresponds to 1.2 to 1.8 and 17.7 to greater than 48 times the recommended field dose in Ontario. Norsworthy et al. (2010) [20] reported on GR giant ragweed from Tennessee. In their greenhouse study, the LD required to kill $50 \%$ and $90 \%$ of the resistant accession was 2176 and $12400 \mathrm{~g} \cdot$ a.e. $\mathrm{ha}^{-1}$, respectively. In another greenhouse study, GR giant ragweed biotypes from Arkansas were not as resistant as the Tennessee biotypes with an $\mathrm{LD}_{50}$ and $\mathrm{LD}_{90}$ of 765 to 1181 and 2278 to 2753 g.a.e. $h^{-1}$, respectively [19]. In their study, the $L^{2} D_{90}$ values were 2.7 to 3.3 times the normal dose of glyphosate in Arkansas.

The results of this research demonstrated that some giant ragweed biotypes can survive very high doses of glyphosate. Growers will need to alter their weed management practices and no longer rely on glyphosate for the control of GR biotypes. Alternative management strategies may include effective residual herbicides, diverse crop rotation, and the use of effective postemergence herbicides.

\subsection{Postemergence Herbicides}

GR giant ragweed control data at 1 WAA were combined into groups (L1 and L4), and (L2 and L3), whereas L5 was analyzed separately. For the remaining control assessments, data were combined into groups (L1, L4 and L5) and (L2 and L3). At the earliest assessments, all herbicides evaluated increased GR giant ragweed control compared to the weedy check (Table 3). However, glyphosate alone provided up to only $44 \%$ and $50 \%$ control 1 and 2 WAA, respectively. In contrast, glyphosate plus fomesafen provided control equivalent to the weed-free check at L1, L4 and L5 but only $61 \%$ control at L2 and L3, 1 WAA. The difference may be due to larger giant ragweed at the time of application (Table 1). Norsworthy et al. (2010) [20] also reported variable control with fomesafen depending on the size of GR giant ragweed at application. Control with fomesafen applied alone ranged from $27 \%$ to $86 \%$. At $2 \mathrm{WAA}$, cloransulam-methyl alone and with glyphosate also provided control equivalent to the weed-free check (Table 3). Chlorimuron-ethyl, imazethapyr, and imazethapyr plus bentazon applied alone and with glyphosate generally provided similar levels of

Table 3. Percent control of glyphosate-resistant giant ragweed at 1 and 2 weeks after treatment application for various postemergence herbicides $^{\mathrm{a}-\mathrm{g}}$.

\begin{tabular}{|c|c|c|c|c|c|c|}
\hline \multirow[b]{2}{*}{ Treatment } & \multirow[b]{2}{*}{ Rate } & \multicolumn{3}{|c|}{ Control 1 WAA } & \multicolumn{2}{|c|}{ Control 2 WAA } \\
\hline & & $\mathrm{L} 1$ and $\mathrm{L} 4$ & L2 and L3 & L5 & L1, L4 and L5 & $L 2$ and $L 3$ \\
\hline & $\left(\mathrm{g} \cdot \mathrm{ae} / \mathrm{ai} \cdot \mathrm{ha}^{-1}\right)$ & 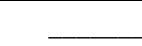 & 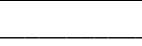 & $\%$ & & - \\
\hline Weedy check & & $0 \mathrm{~g}$ & $0 \mathrm{e}$ & $0 \mathrm{~h}$ & $0 \mathrm{~g}$ & $0 \mathrm{e}$ \\
\hline Weed-free check & & $100 \mathrm{a}$ & $100 \mathrm{a}$ & $100 \mathrm{a}$ & $100 \mathrm{a}$ & $100 \mathrm{a}$ \\
\hline Chlorimuron-ethyl $^{\text {bd }}$ & 9 & 66 cde & $63 \mathrm{~b}$ & $44 \mathrm{~g}$ & $60 \mathrm{e}$ & $68 \mathrm{bc}$ \\
\hline Cloransulam-methyl ${ }^{\mathrm{ce}}$ & 17.5 & $78 \mathrm{bcd}$ & $66 \mathrm{~b}$ & 50 efg & $93 \mathrm{ab}$ & $90 \mathrm{a}$ \\
\hline Fomesafen ${ }^{\mathrm{f}}$ & 240 & $80 \mathrm{bc}$ & $44 \mathrm{~cd}$ & $86 \mathrm{~b}$ & 66 de & $27 \mathrm{~d}$ \\
\hline Glyphosate & 900 & $43 \mathrm{f}$ & $44 \mathrm{~cd}$ & $43 \mathrm{~g}$ & $45 \mathrm{f}$ & $50 \mathrm{c}$ \\
\hline Imazethapyr ${ }^{\mathrm{cd}}$ & 100 & 55 ef & $41 \mathrm{~d}$ & 57 ef & $73 \mathrm{~cd}$ & $52 \mathrm{c}$ \\
\hline Imazethapyr + bentazon $^{\mathrm{d}}$ & $75+840$ & 58 ef & 52 bcd & $48 \mathrm{fg}$ & 71 de & $61 \mathrm{c}$ \\
\hline Glyphosate + chlorimuron-ethyl ${ }^{\text {bd }}$ & $900+9$ & 64 cde & $65 \mathrm{~b}$ & $70 \mathrm{c}$ & 68 de & $69 \mathrm{bc}$ \\
\hline Glyphosate + cloransulam-methyl ${ }^{\text {ce }}$ & $900+17.5$ & 62 cdef & $69 \mathrm{~b}$ & 58 de & $83 \mathrm{bc}$ & $83 \mathrm{ab}$ \\
\hline Glyphosate + fomesafen $^{f}$ & $900+240$ & $90 \mathrm{ab}$ & $61 \mathrm{bc}$ & $93 \mathrm{ab}$ & $86 \mathrm{~b}$ & $50 \mathrm{c}$ \\
\hline Glyphosate + imazethapyr ${ }^{\text {cd }}$ & $900+100$ & 60 def & $62 \mathrm{~b}$ & $67 \mathrm{~cd}$ & $73 \mathrm{~cd}$ & $68 \mathrm{bc}$ \\
\hline Glyphosate + imazethapyr + bentazon $^{\mathrm{d}}$ & $900+75+840$ & 58 ef & $60 \mathrm{bc}$ & $57 \mathrm{ef}$ & 66 de & 66 bc \\
\hline
\end{tabular}

${ }^{\mathrm{a}}$ Abbreviations: WAA, week after application. ${ }^{\mathrm{b}}$ Included non-ionic surfactant $(0.2 \% \mathrm{vol} / \mathrm{vol}) .{ }^{\mathrm{c}}$ Included non-ionic surfactant $\left(0.25 \%\right.$ vol/vol). ${ }^{\mathrm{d}}$ Included $28 \%$ UAN ( $\left.2 \mathrm{~L} \cdot \mathrm{ha}^{-1}\right)$. ${ }^{\mathrm{e}}$ Included $28 \% \mathrm{UAN}(2.5 \% \mathrm{vol} / \mathrm{vol}) .{ }^{\mathrm{f}}$ Included crop oil concentrate $(0.5 \% \mathrm{vol} / \mathrm{vol}) .{ }^{{ }^{\mathrm{g}}}$ Means followed by the same letter within a column are not significantly different according to Fisher's Protected LSD at $\mathrm{P}<0.05$. 
control which ranged from $41 \%$ to $73 \%$ (Table 3). Taylor et al. (2002) [33] applied chlorimuron-ethyl and imazethapyr at higher rates of 13 and $140 \mathrm{~g} \cdot$ a.i. $\cdot \mathrm{ha}^{-1}$, respectively, and reported control within the range reported in this study 2 WAA. At the earliest assessments, adding glyphosate to some herbicides improved control compared to single applications. Control with imazethapyr at L2, L3 and L5, as well as chlorimuron-ethyl at L5 improved when tank mixed with glyphosate 1 WAA. At 2 WAA, control with fomesafen increased when tank mixed with glyphosate.

At 4 and 8 WAA, GR giant ragweed control was improved with all herbicide treatments compared to the weedy check (Table 4). However, glyphosate applied alone provided only $43 \%$ to $57 \%$ and $29 \%$ to $41 \%$ control 4 and 8 WAA, respectively. This is consistent with Stachler (2008) [17] who reported 32\% GR giant ragweed control with glyphosate applied at $840 \mathrm{~g} \cdot$ a.e. $\cdot \mathrm{ha}^{-1}$. Similarly, Johnson et al. (2007) [23] reported 39\% control with glyphosate applied at a higher rate of $1680 \mathrm{~g}$. a.e. $\mathrm{ha}^{-1}$. In contrast, cloransulam-methyl applied alone provided $93 \%$ to $99 \%$ control, which was equivalent to the weedfree check. In previous research, cloransulam-methyl applied POST provided up to $88 \%$ control of 10 to $15 \mathrm{~cm}$ tall giant ragweed [34]. Norsworthy et al. (2011) [19] reported 98\% GR giant ragweed control when cloransulam-methyl was applied to 12 to $15 \mathrm{~cm}$ tall plants. In contrast, other studies have reported variable giant rag- weed control with cloransulam-methyl [33]. In general, cloransulam-methyl was antagonized by the addition of glyphosate and control ranged from $80 \%$ to $92 \%$. It is suggested that this decrease in control is due to rapid necrosis of the mature leaf tissue after the application of glyphosate which may reduce the absorption and/or translocation ofcloransulam-methyl. Glyphosate plus fomesafen was generally more effective than fomesafen applied alone but control was variable at the later assessments (Table 4). Glyphosate plus fomesafen provided $84 \%$ to $94 \%$ control of giant ragweed in Illinois [35]. In another study, fomesafen provided $64 \%$ to $86 \%$ control of three to five $\mathrm{cm}$ tall plants six weeks after treatment [36]. Norsworthy et al. (2011) [19] reported $100 \%$ GR giant ragweed control with fomesafen in a greenhouse study. Chlorimuron-ethyl applied alone or with glyphosate provided $41 \%$ to $69 \%$ and $44 \%$ to $71 \%$ control, respectively. GR giant ragweed from Arkansas was controlled $68 \%$ with chlorimuron-ethyl applied in the greenhouse at $6 \mathrm{~g} \cdot$ a.i. $\cdot \mathrm{ha}^{-1}$ [19]. Control with imazethapyr and imazethapyr plus bentazon applied alone or with glyphosate was variable and ranged from $25 \%$ to $82 \%$. Hoss et al. (2003) [37] reported up to only $46 \%$ giant ragweed control with imazethapyr applied POST at a lower rate of $70 \mathrm{~g} \cdot$ a.i. $\cdot \mathrm{ha}^{-1}$.

Cloransulam-methyl reduced giant ragweed density 98\% relative to the weedy check (Table 5). In a previous study, cloransulam-methyl reduced giant ragweed den-

Table 4. Percent control of glyphosate-resistant giant ragweed at 2 and 4 weeks after treatment application for various postemergence herbicides $^{\mathrm{a}-\mathrm{g}}$.

\begin{tabular}{|c|c|c|c|c|c|}
\hline \multirow[b]{2}{*}{ Treatment } & \multirow[b]{2}{*}{ Rate } & \multicolumn{2}{|c|}{ Control 4 WAA } & \multicolumn{2}{|c|}{ Control 8 WAA } \\
\hline & & L1, L4 and L5 & $\mathrm{L} 2$ and $\mathrm{L3}$ & L1, L4 and L5 & $L 2$ and $L 3$ \\
\hline & $\left(\mathrm{g} \cdot \mathrm{ae} / \mathrm{ai} \cdot \mathrm{ha} \mathrm{H}^{-1}\right)$ & 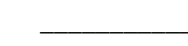 & 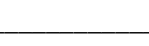 & 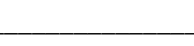 & - \\
\hline Weedy check & & $0 \mathrm{~g}$ & $0 \mathrm{e}$ & $0 \mathrm{~g}$ & $0 \mathrm{~d}$ \\
\hline Weed-free check & & $100 \mathrm{a}$ & $100 \mathrm{a}$ & $100 \mathrm{a}$ & $100 \mathrm{a}$ \\
\hline Chlorimuron-ethyl $^{\mathrm{bd}}$ & 9 & $46 \mathrm{f}$ & $69 \mathrm{bc}$ & $42 \mathrm{ef}$ & $41 \mathrm{~cd}$ \\
\hline Cloransulam-methyl $^{\text {ce }}$ & 17.5 & 99 a & 98 a & $96 \mathrm{ab}$ & $93 \mathrm{ab}$ \\
\hline Fomesafen ${ }^{f}$ & 240 & $51 \mathrm{f}$ & 29 de & 38 ef & $11 \mathrm{~d}$ \\
\hline Glyphosate & 900 & $43 \mathrm{f}$ & 57 c & $29 \mathrm{f}$ & $41 \mathrm{~cd}$ \\
\hline Imazethapyr ${ }^{\text {cd }}$ & 100 & $78 \mathrm{~cd}$ & $59 \mathrm{c}$ & 54 de & $25 \mathrm{~d}$ \\
\hline 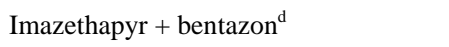 & $75+840$ & 76 cde & $53 \mathrm{~cd}$ & 52 de & $30 \mathrm{~cd}$ \\
\hline Glyphosate + chlorimuron-ethyl ${ }^{\text {bd }}$ & $900+9$ & 66 e & $71 \mathrm{bc}$ & 44 ef & $66 \mathrm{bc}$ \\
\hline Glyphosate + cloransulam-methyl ${ }^{\text {ce }}$ & $900+17.5$ & $92 \mathrm{~b}$ & $88 \mathrm{ab}$ & $81 \mathrm{bc}$ & $80 \mathrm{~b}$ \\
\hline Glyphosate + fomesafen $^{\mathrm{f}}$ & $900+240$ & $84 \mathrm{c}$ & $57 \mathrm{c}$ & $65 \mathrm{~cd}$ & $32 \mathrm{~cd}$ \\
\hline Glyphosate + imazethapyr ${ }^{\text {cd }}$ & $900+100$ & $82 \mathrm{~cd}$ & $69 \mathrm{bc}$ & 51 de & $41 \mathrm{~cd}$ \\
\hline Glyphosate + imazethapyr + bentazon $^{\mathrm{d}}$ & $900+75+840$ & 74 de & $69 \mathrm{bc}$ & 43 ef & $35 \mathrm{~cd}$ \\
\hline
\end{tabular}

${ }^{a}$ Abbreviations: WAA, week after application. ${ }^{\mathrm{b}}$ Included non-ionic surfactant $(0.2 \% \mathrm{vol} / \mathrm{vol})$. ${ }^{\mathrm{C}}$ Included non-ionic surfactant $\left(0.25 \%\right.$ vol/vol). ${ }^{\mathrm{d}}$ Included $28 \%$

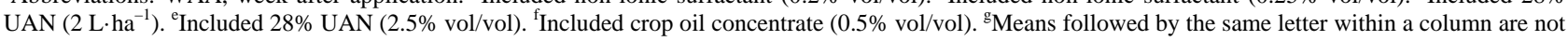
significantly different according to Fisher's Protected LSD at $\mathrm{P}<0.05$. 
standalone treatment. In contrast, glyphosate applied sity up to $90 \%$ [34]. Glyphosate plus cloransulam-methyl reduced density $90 \%$, but was not as effective as the alone reduced density only $50 \%$, and was equivalent to the weedy check. Fomesafen alone also failed to effectively reduce giant ragweed density and was equivalent to the weedy check. This is in contrast to Baysinger and Sims (1992) [36] who reported up to $87 \%$ reduction in giant ragweed density when fomesafen was applied at a higher rate of $350 \mathrm{~g} \cdot$ a.i. $\cdot \mathrm{ha}^{-1}$. Chlorimuron-ethyl, imazethapyr and imazethapyr plus bentazon alone and with glyphosate reduced density $55 \%$ to $63 \%$ and did not reduce density any more than glyphosate applied alone. This is consistent with previous research where chlorimuron-ethyl and imazethapyr reduced giant ragweed density 0 to $68 \%$ and $65 \%$ to $78 \%$, respectively [36].

Reduction in giant ragweed shoot dry weight correlated with control ratings (Table 5). Cloransulam-methyl alone and with glyphosate reduced shoot dry weight 95 to $99 \%$ and were once again the most effective treatments evaluated. Glyphosate alone reduced shoot dry weight $62 \%$ compared to the weedy check. Chlorimuronethyl, imazethapyr and imazethapyr plus bentazon applied alone or with glyphosate did not effectively reduce giant ragweed shoot dry weight, and were equivalent to glyphosate treatment alone (Table 5). Glyphosate plus fomesafen reduced shoot dry weight $80 \%$ and was an improvement over fomesafen alone.
Soybean yield data from L2, L3 and L5 could be combined, and L4 was analyzed separately. Soybean emergence at L4 was delayed due to shallow planting depth which resulted in lower yield compared to the other locations. GR giant ragweed reduced soybean yield up to 73\% (Table 5). Poor giant ragweed control with glyphosate resulted in soybean yield equivalent to the weedy check. Chlorimuron-ethyl, fomesafen, imazethapyr and imazethapyr plus bentazon applied alone or with glyphosate failed to adequately control giant ragweed and resulted in soybean yield equivalent to the weedy check (Table 5). In contrast, cloransulam-methyl alone resulted in soybean yield equivalent to the weed-free check. Glyphosate plus cloransulam-methyl was the next best treatment but still resulted in $32 \%$ to $40 \%$ reduction in soybean yield. This further suggests that antagonism of cloransulam-methyl from glyphosate leads to reduced control of GR giant ragweed.

\section{Conclusion}

Giant ragweed biotypes from Ontario can survive doses of glyphosate in excess of 18 times the normal field dose. Growers will need to rely on alternative measures for the control of GR giant ragweed biotypes. The use of alternative herbicides with different modes of action could be a part of an integrated weed management program. Based on the results of this study, cloransulam-methyl applied

Table 5. Glyphosate-resistant giant ragweed density and shoot dry weight, and soybean yield for various postemergence herbicides $^{\mathrm{a}-\mathrm{g}}$.

\begin{tabular}{|c|c|c|c|c|c|}
\hline \multirow[b]{2}{*}{ Treatment } & & \multirow{2}{*}{$\begin{array}{c}\text { Density } \\
\text { Combined }\end{array}$} & \multirow{2}{*}{$\begin{array}{c}\text { Shoot dry weight } \\
\text { Combined }\end{array}$} & \multicolumn{2}{|c|}{ Soybean yield } \\
\hline & & & & L2, L3 and L5 & $\mathbf{L 4}$ \\
\hline & $\left(\mathrm{g} \cdot \mathrm{ae} / \mathrm{ai} \cdot \mathrm{ha}^{-1}\right)$ & $\left(\right.$ no. $\left.\cdot \mathrm{m}^{-2}\right)$ & $\left(g \cdot m^{-2}\right)$ & \multicolumn{2}{|c|}{$\left(\mathrm{MT} \cdot \mathrm{ha}^{-1}\right)$} \\
\hline Weedy check & & $40 \mathrm{e}$ & 61.9 e & $1.18 \mathrm{~d}$ & $0.57 \mathrm{c}$ \\
\hline Weed-free check & & 0 a & $0.0 \mathrm{a}$ & $3.73 \mathrm{a}$ & $2.10 \mathrm{a}$ \\
\hline Chlorimuron-ethyl $^{\mathrm{bd}}$ & 9 & $15 \mathrm{~cd}$ & $20.7 \mathrm{~cd}$ & $1.68 \mathrm{~d}$ & $0.64 \mathrm{c}$ \\
\hline Cloransulam-methyl ${ }^{\mathrm{ce}}$ & 17.5 & 1 a & $0.3 \mathrm{~b}$ & $3.29 \mathrm{ab}$ & $1.78 \mathrm{a}$ \\
\hline Fomesafen $^{\mathrm{f}}$ & 240 & 20 cde & $32.3 \mathrm{~d}$ & $1.34 \mathrm{~d}$ & $0.50 \mathrm{c}$ \\
\hline Glyphosate & 900 & 20 de & $23.3 \mathrm{~cd}$ & $1.53 \mathrm{~d}$ & $0.59 \mathrm{c}$ \\
\hline Imazethapyr $^{\text {cd }}$ & 100 & $18 \mathrm{~cd}$ & $16.9 \mathrm{c}$ & $1.50 \mathrm{~d}$ & $0.29 \mathrm{c}$ \\
\hline Imazethapyr + bentazon $^{\mathrm{d}}$ & $75+840$ & $18 \mathrm{~cd}$ & $20.1 \mathrm{~cd}$ & $1.57 \mathrm{~d}$ & $0.61 \mathrm{c}$ \\
\hline Glyphosate + chlorimuron-ethyl ${ }^{\text {bd }}$ & $900+9$ & 18 cde & $19.0 \mathrm{~cd}$ & $1.86 \mathrm{~cd}$ & $0.65 \mathrm{c}$ \\
\hline Glyphosate + cloransulam-methyl ${ }^{\text {ce }}$ & $900+17.5$ & $4 \mathrm{~b}$ & $3.1 \mathrm{~b}$ & $2.53 \mathrm{bc}$ & $1.25 \mathrm{~b}$ \\
\hline Glyphosate + fomesafen $^{f}$ & $900+240$ & $9 \mathrm{c}$ & $12.3 \mathrm{c}$ & $1.91 \mathrm{~cd}$ & $0.58 \mathrm{c}$ \\
\hline Glyphosate + imazethapyr ${ }^{\text {cd }}$ & $900+100$ & $18 \mathrm{~cd}$ & $13.3 \mathrm{c}$ & $1.58 \mathrm{~d}$ & $0.55 \mathrm{c}$ \\
\hline Glyphosate + imazethapyr + bentazon ${ }^{\mathrm{d}}$ & $900+75+840$ & $18 \mathrm{~cd}$ & $13.7 \mathrm{c}$ & $1.54 \mathrm{~d}$ & $0.39 \mathrm{c}$ \\
\hline
\end{tabular}

${ }^{a}$ Abbreviations: WAA, week after application. ${ }^{b}$ Included non-ionic surfactant $(0.2 \% \mathrm{vol} / \mathrm{vol}) .{ }^{\mathrm{c}}$ Included non-ionic surfactant $(0.25 \% \mathrm{vol} / \mathrm{vol}) .{ }^{\mathrm{d}}$ Included $28 \%$ UAN ( $\left.2 \mathrm{~L} \cdot \mathrm{ha}^{-1}\right)$. ${ }^{\mathrm{e}}$ Included $28 \%$ UAN $(2.5 \% \mathrm{vol} / \mathrm{vol}) .{ }^{\mathrm{f}}$ Included crop oil concentrate $(0.5 \% \mathrm{vol} / \mathrm{vol}) .{ }^{\mathrm{g}}$ Means followed by the same letter within a column are not significantly different according to Fisher's Protected LSD at $\mathrm{P}<0.05$. 
POST can be an effective option for the control of GR giant ragweed. However, growers should be advised that some GR giant ragweed biotypes from Ontario have also evolved resistance to cloransulam-methyl (unpublished data). This research also suggests that the rapid necrosis after the application of glyphosate may antagonize cloransulam-methyl. Further research is needed to confirm multiple herbicide resistance in giant ragweed in Ontario.

\section{Acknowledgements}

The authors acknowledge Adam Pfeffer, Christy Shropshire and Chris Kramer for their expertise and technical assistance in these studies. Funding for this project was provided in part by Monsanto Canada Inc., the Grain Farmers of Ontario and the Agricultural Adaptation Council through the Canadian Agricultural Adaptation Program.

\section{REFERENCES}

[1] J. E. Franz, M. K. Mao and J. A. Sikorski, "Glyphosate: A Unique Global Herbicide,” American Chemical Society, Washington, 1997.

[2] S. O. Duke and S. B. Powles, "Glyphosate: A Once-ina-Century Herbicide,” Pest Management Science, Vol. 64, No. 4, 2008, pp.319-325. doi:10.1002/ps.1518

[3] S. B. Powles, "Review. Evolved Glyphosate-Resistant Weeds Around the World: Lessons to be Learnt," Pest Management Science, Vol. 64, No. 4, 2008, pp. 360-365. doi:10.1002/ps. 1525

[4] N. Amrhein, J. Schab and H. C. Steinrücken,“The Mode of Action of the Herbicide Glyphosate," Naturwissenschaften, Vol. 67, No. 7, 1980, pp. 356-357. doi:10.1007/BF01106593

[5] WSSA, "Summary of Herbicide Mechanism of Action According to the Weed Science Society of America," 2011.

http://www.wssa.net/weeds/resistance/wssa.mechanism-o faction.pdf

[6] G. M. Dill, R. D. Sammons, P. C. C. Feng, F. Kohn, K. Kretzmer, A. Mehrsheikh, M. Bleeke, J. L. Honegger, D. Farmer, D. Wright and E. A. Haupfear, "Glyphosate: Discovery, Development, Applications, and Properties," In: V. K. Nandula, Ed., Glyphosate Resistance in Crops and Weeds: History, Development, and Management, John Wiley and Sons, Inc., Hoboken, 2010, pp. 1-33. doi:10.1002/9780470634394.ch1

[7] K. N. Reddy and J. K. Norsworthy, "Glyphosate-Resistant Crop Production Systems: Impact on Weed Species Shifts,” In: V. K. Nandula, Ed., Glyphosate Resistance in Crops and Weeds: History, Development, and Management, John Wiley and Sons, Inc., Hoboken, 2010, pp. 165-184. doi:10.1002/9780470634394.ch9

[8] P. C. C. Feng, C. A. CaJacob, S. J. Martino-Catt, R. E. Cerny, G. A. Elmore, G. R. Heck, J. Huang, W. M. Kruger, M. Malven, J. A. Miklos and S. R. Padgette,
"Glyphosate-Resistant Crops: Developing the Next Generation Products,” In: V. K. Nandula, Ed., Glyphosate Resistance in Crops and Weeds: History, Development, and Management, John Wiley and Sons, Inc., Hoboken, 2010, pp. 45-65. doi:10.1002/9780470634394.ch3

[9] V. K. Nandula, "Herbicide Resistance: Definitions and Concepts,” In: V. K. Nandula, Ed., Glyphosate Resistance in Crops and Weeds: History, Development, and Management, John Wiley and Sons, Inc., Hoboken, 2010, pp. 35-43. doi:10.1002/9780470634394.ch2

[10] D. L. Shaner, R. B. Lindenmeyer and M. H. Ostlie, "What Have the Mechanisms of Resistance to Glyphosate Taught Us?” Pest Management Science, Vol. 68, No. 1, 2012, pp. 3-9. doi:10.1002/ps.2261

[11] USDA, “National Agricultural Statistics Service: Agricultural Chemical Use Database,” 2012. http://www.pestmanagement.info/nass/

[12] S. O. Duke and S. B. Powles, “Glyphosate-Resistant Crops and Weeds: Now and in the Future," AgBioForum, Vol. 12, No. 3-4, 2009, pp. 346-357.

[13] L. J. Lee and J. Ngim, “A First Report of GlyphosateResistant Goosegrass (Eleusine indica (L) Gaertn) in Malaysia,” Pest Management Science, Vol. 56, No. 4, 2000, pp. 336-339.

doi:10.1002/(SICI)1526-4998(200004)56:4<336::AID-PS 123>3.0.CO;2-8

[14] S. B. Powles, D. F. Lorraine-Colwill, J. J. Dellow and C. Preston, "Evolved Resistance to Glyphosate in Rigid Ryegrass (Lolium rigidum) in Australia,” Weed Science, Vol. 46, No. 5, 1998, pp. 604-607.

[15] M. J. VanGessel, “Glyphosate-Resistant Horseweed from Delaware,” Weed Science, Vol. 49, No. 6, 2001, pp. 703705.

doi:10.1614/0043-1745(2001)049[0703:RPRHFD]2.0.CO ;2

[16] I. Heap, "International Survey of Herbicide Resistant Weeds,” 2012. http://www.weedscience.org/In.asp

[17] J. M. Stachler, "Characterization and Management of Glyphosate-Resistant Giant Ragweed (Ambrosia trifida L.) and Horseweed [Conyza canadensis (L.) Cronq.]," Ph.D. Dissertation, The Ohio State University, Columbus, 2008, pp. 60-107.

[18] A. M. Westhoven, V. M. Davis, K. D. Gibson, S. C. Weller and W. G. Johnson, "Field Presence of GlyphosateResistant Horseweed (Conyza canadensis), Common Lambsquarters (Chenopodium album), and Giant Ragweed (Ambrosia trifida) Biotypes with Elevated Tolerance to Glyphosate,” Weed Technology, Vol. 22, No. 3, 2008, pp. 544-548. doi:10.1614/WT-08-006.1

[19] J. K. Norsworthy, D. Riar, P. Jha and R. C. Scott, "Confirmation, Control, and Physiology of Glyphosate-Resistant Giant Ragweed (Ambrosia trifida) in Arkansas," Weed Technology, Vol. 25, No. 3, 2011, pp. 430-435. doi:10.1614/WT-D-10-00155.1

[20] J. K. Norsworthy, P. Jha, L. E. Steckel and R. C. Scott, "Confirmation and Control of Glyphosate-Resistant Giant Ragweed (Ambrosia trifida) in Tennessee," Weed Technology, Vol. 24, No. 1, 2010, pp. 64-70. 
doi:10.1614/WT-D-09-00019.1

[21] P. H. Sikkema, N. Soltani, P. J. Smith, C. Shropshire, M. B. Lawton and F. J. Tardif, "Suspected Glyphosate-Resistant Giant Ragweed in Ontario," Proceedings of the 64th Annual Meeting of the North Central Weed Science Society, Vol. 64, No. 167, 2009.

[22] J. P. Vink, P. H. Sikkema, F. J. Tardif, D. E. Robinson and M. B. Lawton, "Glyphosate-Resistant Giant Ragweed in Ontario: Survey and Control," Proceedings of the 66th Annual Meeting of the North Central Weed Science Society, Vol. 66, No. 87, 2011.

[23] B. Johnson, M. Loux, D. Nordby, C. Sprague, G. Nice, A. Westhoven and J. Stachler, "Biology and Management of Giant Ragweed,” 2007. http://www.ces.purdue.edu/extmedia/BP/GWC-12.pdf

[24] K. Knowlton, "Climate Change and Ragweed Pollen: A Double Whammy for Public Health," Proceedings of the 66th Annual Meeting of the North Central Weed Science Society, Vol. 66, No. 196, 2011.

[25] T. M. Webster, M. M. Loux, E. E. Regnier and S. K. Harrison, "Giant Ragweed (Ambrosia trifida) Canopy Architecture and Interference Studies in Soybean (Glycine max)," Weed Technology, Vol. 8, No. 3, 1994, pp. 559564.

[26] S. K. Harrison, E. E. Regnier, J. T. Schmoll and J. E. Webb, "Competition and Fecundity of Giant Ragweed in Corn,” Weed Science, Vol. 49, No. 2, 2001, pp. 224-229. doi:10.1614/0043-1745(2001)049[0224:CAFOGR]2.0.C $\underline{\mathrm{O} ; 2}$

[27] H. A. Abul-Fatih and F. A. Bazzaz, "The Biology of Ambrosia trifida L. II. Germination, Emergence, Growth, and Survival," New Phytologist, Vol. 83, No. 3, 1979, pp. 817-827. doi:10.1111/j.1469-8137.1979.tb02313.x

[28] E. W. Stoller and L. M. Wax, "Periodicity of Germination and Emergence of Some Annual Weeds," Weed Science, Vol. 21, No. 6, 1973, pp. 574-580.

[29] B. J. Schutte, E. E. Regnier and S. K. Harrison, "The Association between Seed Size and Seed Longevity Among Maternal Families in Ambrosia trifida L. Populations,” Seed Science Research, Vol. 18, No. 4, 2008, pp.

\section{1-211. doi:10.1017/S0960258508082974}

[30] S. Bowley, “A Hitchhiker's Guide to Statistics in Plant Biology,” 2nd Edition, Any Old Subject Books, Guelph, 2008.

[31] S. S. Seefeldt, J. E. Jensen and E. P. Fuerst, "Log-Logistic Analysis of Herbicide Dose-Response Relationships," Weed Technology, Vol. 9, No. 2, 1995, pp. 218-227.

[32] C. B. Brabham, C. K. Gerber and W. G. Johnson, "Fate of Glyphosate-Resistant Giant Ragweed (Ambrosia trifida) in the Presence and Absence of Glyphosate," Weed Science, Vol. 59, No. 4, 2011, pp. 506-511. doi:10.1614/WS-D-11-00050.1

[33] J. B. Taylor, M. M. Loux, S. K. Harrison and E. E. Regnier, "Response of ALS-Resistant Common Ragweed (Ambrosia artemisiifolia) and Giant Ragweed (Ambrosia trifida) to ALS-Inhibiting and Alternative Herbicides," Weed Technology, Vol. 16, No. 4, 2002, pp. 815-825. doi:10.1614/0890-037X(2002)016[0815:ROARCR]2.0.C $\underline{\mathrm{O} ; 2}$

[34] R. J. Franey and S. E. Hart, "Time of Application of Cloransulam for Giant Ragweed (Ambrosia trifida) Control in Soybean (Glycine max)," Weed Technology, Vol. 13, No. 4, 1999, pp. 825-828.

[35] M. L. Wiesbrook, W. G. Johnson, S. E. Hart, P. R. Bradley and L. M. Wax, "Comparison of Weed Management Systems in Narrow-Row, Glyphosate- and GlufosinateResistant Soybean (Glycine max)," Weed Technology, Vol. 15, No. 1, 2001, pp. 122-128. doi:10.1614/0890-037X(2001)015[0122:COWMSI]2.0.C $\underline{\mathrm{O} ; 2}$

[36] J. A. Baysinger and B. D. Sims, "Giant Ragweed (Ambrosia trifida) Control in Soybean (Glycine max)," Weed Technology, Vol. 6, No. 1, 1992, pp. 13-18.

[37] N. E. Hoss, K. Al-Khatib, D. E. Peterson and T. M. Loughin, "Efficacy of Glyphosate, Glufosinate, and Imazethapyr on Selected Weed Species," Weed Science, Vol. 51, No. 1, 2003, pp. 110-117. doi:10.1614/0043-1745(2003)051[0110:EOGGAI]2.0.CO ;2 